\title{
Professional Safety in the daily life of primary health care: grounded theory
}

\author{
Segurança do Profissional no cotidiano da atenção primária à saúde: uma teoria fundamentada nos dados
}

Seguridad Profesional en la vida diaria de la atención primaria de salud: una teoría fundamentada

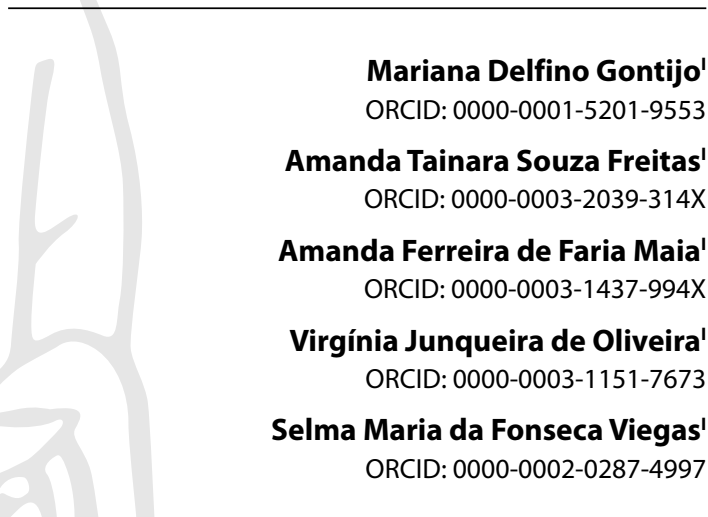

'Universidade Federal de São João del-Rei. Divinópolis, Minas Gerais, Brazil.

How to cite this article: Gontijo MD, Freitas ATS, Maia AFF, Oliveira VJ, Viegas SMF. Professional safety in the daily life of primary health care: grounded theory. Rev Bras Enferm. 2022;75(2):e20210033. https://doi.org/10.1590/0034-7167-2021-0033

Corresponding author:

Selma Maria da Fonseca Viegas

E-mail: selmaviegas@ufsj.edu.br

EDITOR IN CHIEF: Antonio José de Almeida Filho ASSOCIATE EDITOR: Maria Itayra Padilha

Submission: 02-20-2021

Approval: 05-24-202

\begin{abstract}
Objective: to understand Professional Safety in daily life in Primary Health Care. Methods: this is a study on the Grounded Theory method and the Symbolic Interactionism theoretical framework with 82 health professionals. Results: it presents the category"Professional Safety in Daily Life in Primary Health Care: a Grounded Theory" and two subcategories determining and conditioning Professional Safety in PHC: professional training, infrastructure, support and technical responsibility; Professional Safety: physical protection, psychological support distress and feelings reveal the (un)safe conditions. Professional Safety is mentioned in several dimensions that include professionals' knowledge, decision-making skills, the practice of the profession and what regulates it, the structure and organization of the Unified Health System and services, permanent education. It presents the context of primary care and the factors that impact an (unsafe) work. Final considerations: this study contributes to reflect on Professional Safety to strengthen safety culture in Primary Health Care.

Descriptors: Safety; Primary Health Care; Working Conditions; Grounded Theory; Nursing.
\end{abstract}

\section{RESUMO}

Objetivo: compreender a Segurança do Profissional em atuação no cotidiano da atenção primária à saúde. Métodos: estudo sob o método da Teoria Fundamentada nos Dados e do referencial teórico do Interacionismo Simbólico com 82 profissionais de saúde. Resultados: apresenta a categoria Segurança do Profissional no Cotidiano da Atenção Primária à Saúde: uma Teoria Fundamentada nos Dados e duas subcategorias Determinantes e condicionantes da Segurança do Profissional na APS: formação profissional, infraestrutura, apoio e responsabilidade técnica; Segurança do Profissional: proteção física, apoio psicológico, sofrimento e sentimentos revelam as condições (in)seguras. A Segurança do Profissional é referida em várias dimensões que passam pelo conhecimento do profissional, as competências para tomada de decisão, 0 exercício da profissão e o que a regulamenta, a estrutura e organização do Sistema Único de Saúde e dos serviços, a educação permanente. Apresenta o contexto da atenção primária e os fatores que impactam na atuação in(segura). Considerações finais: este estudo contribui com a reflexão sobre a Segurança do Profissional a fim de fortalecer a cultura de segurança na Atenção Primária à Saúde.

Descritores: Segurança; Atenção Primária à Saúde; Condições de Trabalho; Teoria Fundamentada; Enfermagem.

\section{RESUMEN}

Objetivo: comprender la Seguridad del Profesional que trabaja en la vida diaria de la Atención Primaria de Salud. Métodos: estudio utilizando el método de la Teoría Fundamentada y el marco teórico del Interaccionismo Simbólico con 82 profesionales de la salud. Resultados: presenta la categoría "Seguridad Profesional en la Vida Diaria de la Atención Primaria de Salud: una Teoría Fundamentada" y dos subcategorías Determinantes y Condicionadores de la Seguridad Profesional en la APS: formación profesional, infraestructura, soporte y responsabilidad técnica; Seguridad profesional: la protección física, el apoyo psicológico, el sufrimiento y los sentimientos revelan las condiciones (in)seguras. La Seguridad Profesional se menciona en varias dimensiones que incluyen el conocimiento del profesional, la capacidad de decisión, el ejercicio de la profesión y lo que la regula, la estructura y organización del Sistema Único de Salud y los servicios, la educación permanente. Presenta el contexto de la atención primaria y los factores que impactan el desempeño inseguro. Consideraciones finales: este estudio contribuye a la reflexión sobre Seguridad Profesional para fortalecer la cultura de seguridad en Atención Primaria de Salud.

Descriptores: Seguridad; Atención Primaria de Salud; Condiciones de Trabajo; Teoria Fundamentada; Enfermería. 


\section{INTRODUCTION}

The context of multidisciplinary work in Primary Health Care (PHC) is configured as a dynamic setting, in which a culture of safety presents itself in a building movement, based on strategies and management tools of work processes, to improve the quality of care provided in primary care in the Unified Health System (SUS - Sistema Único de Saúde). In this process of improving care, welcoming contributes to qualifying health systems, enabling users to access comprehensive and meaningful care, through multidisciplinarity, intersectoriality and the implementation of the constitutional principles of SUS ${ }^{(1)}$.

User assistance must be comprehensive and the professional must aim at valuing the objective and subjective aspects, the uniqueness of each subject, respecting the precepts of each and the community in the co-production of health. Therefore, comprehensiveness has been discussed as a gear in the processes of changes in health care, with a view to ending the fragmentation of care and comprehensive and safe care for people ${ }^{(2)}$.

The construction of good practices aimed at safe care must be worked on in the services. Professionals' work must be guided by conducts that have scientific and ethical support, with adequate and efficient working relationships, in order to strengthen a culture of safety ${ }^{(3)}$.

The safe climate in teamwork, job satisfaction, working conditions and risk management are factors that make it possible to assess the culture of safety in the workplace ${ }^{(4)}$ for Professional and Patient Safety.

Quality is understood as a parameter for assessing the functioning of health services aiming at investigating, establishing and improving work processes through safe care $e^{(5)}$. Health professionals' conceptions of care are focused on the assessment of users' needs. However, quality of care and assistance is compromised due to the difficulties faced in daily life. In this situation, professionals strive to respond to the problems demanded by users, but they face limits and difficulties that prevent them from acting to solve health demands in a safe way ${ }^{(6)}$.

Some factors compromise Health Care and Professional Safety to good practice. Among the factors that hinder the development of safe actions, the scarcity of human resources, the great demand for care, the heavy workload and new technologies unknown by professionals stand out ${ }^{(7)}$. Moreover, professionals live with unsatisfactory working conditions in PHC, low wages, compliance with regulations, violence, moral harassment and fear, negatively impacting their work and Professional Safety ${ }^{(8)}$.

Quality management must be advocated in services, in order to promote safe care without generating unnecessary damage to professionals and users. It is up to the management to plan and develop joint actions with health professionals, with shared management for service quality as well as strengthening safety culture(9).

A study points out that the Professional Safety theme is little explored in the literature. The studies focus on safety culture and patient safety, indicating the accuracy of research on this topic ${ }^{(10)}$.

Considering the context for safe work and Professional Safety, the question is: how professionals who work in PHC understand Professional Safety for their daily work in the context of PHC? In daily life in PHC, what are the experiences of professionals considering Professional (Un)Safety?
Considering the context of PHC, the "everyday life is not only shown as a setting but, above all, it reveals both the scenes of living and living together"(11).

In this regard, Grounded Theory ${ }^{(12)}$ and Symbolic Interactionism $^{(13)}$ allowed the identification of conceptions on the topic "Professional Safety", the knowledge of the meaning of safety and the meanings that professionals attribute to the factors with which they interact for safe actions and care in daily life in PHC. Thus, the relevance of this study is presented by its originality, when starting a discussion of a little-explored theme, "Professional Safety in Daily Life in Primary Health Care", in order to contribute to safe care and care.

\section{OBJECTIVE}

To understand Professional Safety in daily life in Primary Health Care.

\section{METHODS}

\section{Ethical aspects}

The research was developed in accordance with Resolution CNS/CONEP 466 of December 12, 2012, ensuring the rights and duties that concern research participants, the scientific community and the State. Data collection began after project approval by the Institutional Review Board of Universidade Federal de São João del-Rei/Center-West Campus.

\section{Theoretical-methodological framework}

The theoretical framework of Symbolic Interactionism (SI) $)^{(13)}$ and the methodological framework of Grounded Theory (GT) ${ }^{(12)}$ were designed to understand Professional Safety in daily life in PHC. In $\mathrm{Sl}$, the interpretation of meaning provides the understanding of human behavior in its interactions and processes, allowed to understand the reality and how individuals deal with everyday events and how these influence their experience ${ }^{(13)}$.

GT evolves during real research and is done due to the continuous interaction between analysis and data collection developed in a systematic way ${ }^{(12)}$. SI makes it possible to investigate the meaning that actors give to the objects, people and symbols with which they build their social world. It allows interpreting people's perceptions, the meaning and sense they attribute to things, and the relationship of their narratives with the experiences they have lived ${ }^{(13)}$.

\section{Study design}

This is a study with a qualitative approach, originated from a master's thesis, considering GT and SI. This study was conducted according to the CONsolidated criteria for REporting Qualitative research (COREQ) $)^{(14)}$.

\section{Study setting and research participants}

The survey was conducted in three municipalities in different health regions in the state of Minas Gerais, Brazil, one with a large population and two with a medium-sized one. Participants 
were health professionals from the traditional PHC teams and from FHS teams that provide care to SUS users, with at least six months of experience in PHC. The selection of units was through a random drawing. The approach of research participants was in person, at the PHC Unit, considering the availability of the health professional and the acceptance to voluntarily participate in the research. 82 interviews were conducted with PHC professionals: 14 nurses; 13 nursing techniques; four nursing assistants; eight doctors; a speech therapist, a physical therapist; a psychologist; a nursing resident; 22 community health workers; eight dentists; two techniques in oral health; seven assistants in oral health.

\section{Data source}

Recording in memos and open, intensive ${ }^{(12)}$ individual interviews with a semi-structured script, recorded and transcribed in full were used as sources of evidence.

\section{Data collection and organization}

Data were collected between April 2017 and March 2018 and submitted to analysis at the same time. It is noteworthy that in 2018 , SUS completed 30 years of existence. The collection ended when the theoretical saturation of data occurred, i.e., when no new or relevant data emerged in relation to a category/concept ${ }^{(12)}$.

Qualitative data analysis followed an analytical process of four interdependent steps, demonstrating that analysis is not a structured, static or rigid process: open, axial, selective coding for the process ${ }^{(12)}$.

The first stage consisted of microanalysis, open coding, initiated by thorough reading of the text, analyzing each sentence, and 31 codes were formulated in vivo using the initial ideas and concepts identified, grouping them for theoretical sampling in a classification of similarities and disagreements. After grouping the codes in vivo, five subcategories were created, namely: Determinant and Conditioning Factors of Professional Safety in PHC: professional training, infrastructure, support and technical responsibility; and Professional Safety: physical protection, psychological support, distress and feelings reveal the (un)safe conditions discussed in this article; Understanding SUS from the perspective of PHC professionals; The daily life in PHC and its implication in professionals' work; The impact of management on the SUS context.

For axial coding, there was a conceptual definition of two categories, considering the procedures for examination, interpretation, recognition and grouping of emerging and similar concepts: Daily work in SUS in its third decade: the perspective of Primary Health Care professionals; and Professional Safety in Daily Life in Primary Health Care: a Grounded Theory, which titles this article.

For selective coding, the two originated categories were integrated to form a theoretical scheme, and the data built the theory, derived from a set of concepts, which determined the central category "Professional Safety in Daily Life in Primary Health Care". This theory presents the conceptualization, classification and description of facts, actions and results"signifying the central idea"(12) of the studied object in its real context.

Coding for the process: data analysis in search of a process occurred simultaneously with the other steps, looking for relevant conceptual dimensions and relationships between the concepts identified in the analysis of each researched reality, considering the guiding question: how are the structure, context and conditions related to the process of actions/interactions of professionals and strategies established to respond to issues experienced that bring (un)safety to professionals in their decisions/actions in daily life in PHC?

The paradigm of this phenomenon "Professional Safety in Daily Life in Primary Health Care" is contextualized and analyzed considering the theoretical saturation in the three researched realities, positioning it within the structure of the setting services of this study, identifying the actions/interactions of professionals and working conditions, reported by the 82 participants from 12 professional categories.

\section{RESULTS}

Data analysis allowed the elaboration of a theoretical model, whose category/central concept is named "Professional Safety in Daily Life in Primary Health Care".Two categories/concepts of analysis were identified, which support the formulation of the theoretical model: Daily work in SUS in its third decade: the perspective of Primary Health Care professionals; and Professional Safety in Daily Life in Primary Health Care: a Grounded Theory. Figure 1 schematically represents the interrelationship between the analysis categories.

From data collection and analysis, simultaneously, for the conceptual ordering and theorization in the three cities settings of this study, until theoretical saturation, the phenomenon "Professional Safety in the Daily Life of Primary Health Care" was observed, when identifying the concepts of research participants on the safety context for professional work in daily life in PHC. The organization of data into five subcategories by classification of codes in vivo, i.e., by a set of related concepts, gave rise to two categories. These concepts are revealed in their various dimensions, contemplating the considerations of what Professional Safety is from the perspective of professionals from $14 \mathrm{PHC} / \mathrm{FHS}$ units, and which permeates professional training, infrastructure, technical responsibility, physical protection, psychological support, distress, achievement and taste for work, according to the two analytical categories. In this article, the category/central concept "Professional Safety in the Daily Life of Primary Health Care: a Grounded Theory" was explained, which is composed of two subcategories, presented below.

\section{Determinants and constraints of Professional Safety in Primary Health Care: professional training, infrastructure, support, and technical responsibility}

Professional Safety, in daily life in PHC, brings the concepts and the determinants and conditions of (un)safe conditions.

It is very comprehensive, this term safety, there is my safety of being able to perform the actions. And there's the safety the system gives me, and my Nursing Council safety. There are several levels of safety. When I'm able, it's because I can do it well, effectively and efficiently. A safety regarding my Council, for example, I have to know and be aware of what I can and cannot do. Another safety that I see is the safety of the body that welcomes me, the Municipal Health Department, which has to give me some things to be safe and to be able to treat patients well. $\left(\mathrm{E}_{3}\right)$ 


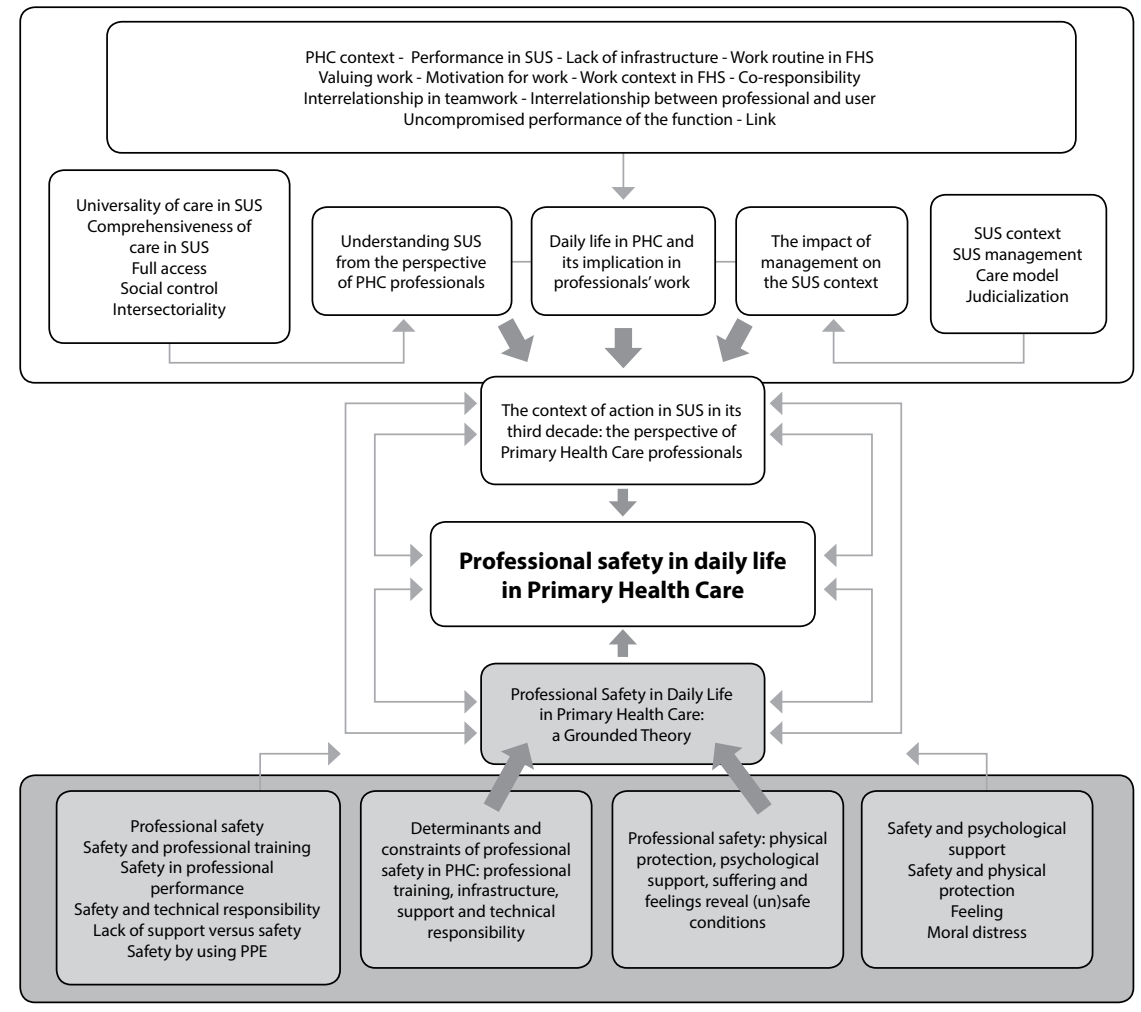

Figure 1 - Professional Safety in Daily Life in Primary Health Care: a Grounded Theory

this FHS. So, if I have any doubts, I ask the doctor, and if she does, she asks me. If you can't solve it, we have the support of the Health Department. So, I feel safe to perform $95 \%$ of the functions. And what I don't really feel safe, I refer. $\left(\mathrm{E}_{3}\right)$

But what about safety in relation to technical responsibility?

Mysafety to be responsible nursing technician (RT). Nurses have a lot of function, this is a very boring conversation, isn't it? Every nurse says that, they don't have time. But, for example, I can't stay in the vaccination room all the time. So, for my safety, I have to trust my technician who is there. And if he has any questions, he'll come afterme. The support of everyone on the team and management, a wellstructured team and goodmanagement, this brings safety. [...] / think there is a lack of support from the management, from the health department. [...] they don't know what's going on here, got it? $\left(\mathrm{E}_{3}\right)$

There is support or lack of professional support and (un)safety:

The support of everyone on the team and management, a well-structured team and good management, this brings safety. [...] / think there is a lack of support from the management, from

Several points are considered, even professional safety, of having the safety as a professional in their attitudes, decision-making, and the safety of the environment for the care itself. $\left(\mathrm{E}_{46}\right)$

Several points are considered, professional safety, having the safety as a professional in your attitudes, in decision-making, and the safety of the environment for care. $\left(\mathrm{E}_{80}\right)$

Professional training is the foundation of safety for professional work. Research participants indicate the strategy of professional training, Permanent Education in PHC:

You have to be confident in what you do and what you say [...]. You have to be based on studies to be able to work [...] and there is a lack of professional training, because health changes every day, disease changes every day, vaccines change every day. Many times, when training comes to $u s$, the thing is already happening. $\left(\mathrm{E}_{29}\right)$

Despite being a work environment that is more peaceful, it is important to train the professional, to bring safety so that I do not do anything that causes harm to the person, and not cause any problems for me. $\left(\mathrm{E}_{56}\right)$

When the team is included in the service, they need to know what the activities are, how they are going to carry them out, what their obligations are and how they are going to fulfill them. $\left(\mathrm{E}_{76}\right)$

The context of safety in professional practice is expressed in the taste for working in PHC and for cooperation and interdisciplinarity:

The things I have doubts about, I have some technical references that support me, and the doctor-nurse partnership is very good in the health department. [...] they don't know what's going on here, got it? As much as we have meetings, going over the problems, but I see that there is a lot from there to here, just play! You have to do this, do that... we go taking, taking, but then what? How is this professional in here? How is this team doing? $\left(\mathrm{E}_{51}\right)$

The context of Professional Safety in the use of Personal Protective Equipment (PPE):

Ah, I think my function depends more on me, for example I have the PPE that I have to use. So, if I'm not using it, it's there. There is and we were never without. There may sometimes be something missing, but it is very rare. There are gloves, caps, masks, glasses, so it depends on the professionals, if they do not use... $\left(\mathrm{E}_{10}\right)$

\section{Professional Safety: physical protection, psychological support, distress and feelings reveal the (un)safe conditions}

Professional Safety determines the need for psychological support:

\begin{abstract}
Ithink psychological safety is lacking, there is no psychological safety to accompany the team [...]/should have support, that would receive you and help you. And you eliminate things and not take them inside your house, to your husband and your children, so you can filter out the good things and how you would do with the bad things, you know? So that it doesn't harm your work or your family life. I don't know if it's psychological support or a person who understands human behavior, how you're going to act and solve things, you know? But I know this is very hard. $\left(\mathrm{E}_{1}\right)$
\end{abstract}

Safety in the face of physical protection becomes a confrontation in the daily life of $\mathrm{PHC}$ professionals in many realities: 
Ah, our safety too, physics, this is becoming a serious problem. We are working without safety in the units and, unfortunately, there is a percentage of the population that arrives fighting, and it is not known who they are dealing with. There are very good people, but there are people capable of anything. So, it is unsafety. We are a little insecure even to educate. There is a lot of invasion of the health unit, this is a fact that bothers me a lot. With me, bullying never happened. Have more physical safety. It's very worrying! $\left(\mathrm{E}_{q}\right)$

Moral distress in the face of Professional Unsafety was reported:

It's sad when you have a patient who needs to be referred to a cardiologist because she has a bundle branch block, and I had to talk to her, unfortunately it will take a while. Knowing that the patient is unable to buy an appointment and that she has a serious problem, and that her appointment will take time, this is very bad for you as a professional. You feel that you are not resolute, understand?! As much as we did, what we could do, you still see that the person is totally surrendered to the System. She can't do anything for herself. In this situation, no, because she has a heart problem, what can she do with it? she needs an expert. [...] Then a patient arrives with an ultra, mega-secreting wound, I'm going to wash it with a serum and put what? I don't have absorbable coverage, the patient cannot afford it, so I'm doing it with wet gauze, with saline. I think I'm not being ethical with myself, with my work, or with the patient. That's my view. So, I'm not doing everything as safely as possible, because I know it's wrong. Then I get anguished, because I know that it won't solve $100 \%$ the patient's problem, but it's not something that depends on me, because I don't have any other option. [...] so, I feel a little insecure about some things that I don't know if it's "my fault" or if it's the System's fault. Example I told you about the patient who has heart disease. Her referral is here, if anything happens to this patient, was I responsible? I keep thinking, you know? To what extent am I responsible for this, understand?! [...] so, working PHC the way it should be, is another point that doesn't give me confidence, because I can't do PHC with six thousand patients. I can't do Primary Care without people, and no one to replace. $\left(\mathrm{E}_{3}\right)$

On a daily basis, PHC professionals reveal themselves in moments of frustration or professional fulfillment, revealing mixed feelings in the face of different experiences:

I love PHC, I really like public health. Although, sometimes, we have difficulties dealing with other sectors. But PHC is the most important level, especially in terms of care, prevention, it is excellent! So, there are mixed feelings. We feel very fulfilled when we are successful at what we do and frustrated when we try to do our best and we can't. [...] because it is a more needy area, everything you do, the people are very grateful. Because that's what they have, so whatever you offer they're very grateful $\left(\mathrm{E}_{64}\right)$.

The inadequate structure and precarious working conditions make Professional Unsafety emerge:

Safety is compromised because we are unable to do the work that should be done. [...] for safety, you have to have the proper working conditions and location, have the resources you need, even medications, exams, to be safe and make sure you are doing a good job. [...] sometimes I feel insecure about not having the resources to treat certain diseases, referrals that we can't get. Things that could be resolved here, we have to forward them because we don't have resources. Even request for exams that I could take myself, but that the Secretariat does not accept, because they have to pass it on to a specialist to request a certain exam. Things that make it difficult could be changed. [...] of course, I think this is a risk we are taking, it implies safety, because it is difficult for the patient to understand what is the professional's fault and what is the system's fault... and this generates unsafety. [...] I think that if the working conditions and service improve, Professional Safety improves, one thing leads to another. $\left(\mathrm{E}_{25}\right)$

\section{DISCUSSION}

The basic purpose of science is to generate theories or expand a theory, since theory is not a reflection of reality, but is a construction of the mind "which allows us to answer certain questions we ask the world, reality"(15).

Theory built from research data tends to look more like reality, improve understanding, offer greater insight, and provide an important guide for action ${ }^{(12)}$.

The constructed theory reveals the reality of professional work, awakens reflection and critical analysis about Professional Safety in $\mathrm{PHC}$, pointing out its constructs. From an analytical point of view, theoretical sampling was important to make comparisons as, on purpose, professionals from 12 categories were interviewed, from $14 \mathrm{PHC} / \mathrm{FHS}$ units in three municipalities, until theoretical saturation was obtained, making it possible to answer the questions formulated to this study.

The conception of the Professional Safety theory in PHC is presented by the research participants in several dimensions, which include professionals' knowledge, decision-making skills, the exercise of the profession and what regulates it, by the structure and organization of SUS and the services and for continuing education.

Health professionals reported difficulties in working in $\mathrm{PHC}$, experiencing anguish with the various obstacles to ensure adequate and safe care, as they are unable to put SUS principles into practice in practice, pointing out several difficulties in their daily lives.

The work context of professionals presents several situations that generate stress, conflicts, moral distress and illness, such as the difficulty of accepting/implementing an user-centered care model, understanding the interdisciplinary role, difficulties in the use of new care technologies in health, with consequent impacts on the quality of life at work, on the care provided ${ }^{(16)}$ and on Professional Safety.

The testimonies revealed precarious working conditions, insufficient human and material resources, inadequate infrastructure, restricted access to other levels of care, making professionals feel limited in their role, causing unsafety for not being able to provide comprehensive care to users.

Another aspect mentioned by the participants was the lack of professional training and the difficulty in carrying it out due to work overload. They reinforce the importance of carrying out Permanent Health Education (PHE), as it affects work and the quality of care, since changes often occur, requiring an update for safe care. Scientific knowledge is produced quickly and exponentially in the field of health, and much of this knowledge is transformed into inputs and techniques to be put into practice by professionals $^{(17)}$, which requires that education be permanent ${ }^{(18)}$. 
The interviewed professionals reported feeling safe to work in their daily work. However, in times of unsafety, they seek support from other health sectors and from other team members, aiming at improving knowledge for safe care.

Interdisciplinarity is essential for resolving the health demands of users, enabling the production and exchange of knowledge for good health practices ${ }^{(6)}$ and, consequently, for Professional Safety.

The action-interaction with the other allows individuals to signify and re-signify their perspectives in relation to care and, thus, progressively, these perspectives lead and help decisionmaking about health care ${ }^{(19)}$.

Among the participants in this study, the nurses reported fear of taking technical responsibility for the unit, since the context in which they live is one of work overload and insufficient human resources, which makes it impossible for them to adequately monitor the nursing team, generating unsafety. Nurses' daily life is marked by the conflict of having to be responsible for the set of activities that make up the dynamics of operation of the units and their specific work ${ }^{(20)}$.

According to COFEN Resolution 0509/16 ${ }^{(21)}$ the Nursing Technical Responsibility Note defines the duties of the technical responsible nurse in health units, aiming to facilitate the exercise of inspection activities, as well as to promote the quality and development of care of nursing in its technical, ethical, and safe aspects for society and nursing professionals.

Thus, carrying out the role of the nursing team needs to be viewed as an attitude contract that aims at a"two-way" relationship between professionals, supported by trust and responsibility between them and with oneself: it is the action-interaction with the other and I can ${ }^{(19)}$.

Participants reported little support from management other than lack of knowledge of team's working conditions and needs. Lack of autonomy, integration in the work environment and management support, unsatisfactory communication and the exclusion of professionals from decisions impact professionals' work $^{(22)}$ and their safety to act. Factors related to work management that cause dissatisfaction among professionals, lack of professional appreciation by the team, managers or even users, are also included. This appreciation implies actions in recognition of the work performed ${ }^{(23)}$, which brings motivation and more safety.

Professionals are faced with the possibility of expanding their autonomy through a sustained practice from the perspective of comprehensiveness and care for users throughout their life cycle; however, there are factors that make this longitudinal care impossible and interfere with quality of care. Among them, working conditions, work overload, infrastructure significantly influence the implementation of these actions, compromising Professional Safety in its daily life ${ }^{(20)}$.

In view of this, the participants in this study see management support and knowledge of the reality of each one and the collective as fundamental for their work, i.e., this interaction is necessary for the construction of new meanings for safe work in $\mathrm{PHC}$ and more professional autonomy.

Regarding the use of PPE, informants reported that they are always available, demonstrated knowledge regarding the need and importance of their use as a form of protection for professionals and users. The risks are inherent to health work, but the professionals who work in PHC do not always use personal protective equipment ${ }^{(24)}$, putting their safety at risk.

In the interactionist approach, people act in relation to things, based on the meaning that things have for them ${ }^{(13)}$. In this sense, health professionals will only use personal protective equipment if they have a meaning of safety/protection for them.

Professional Safety determines the need for psychological support. Health professionals'work is often marked by emotional exhaustion, by the difficulty they have in dealing with the problems experienced in their daily lives, related to the work process, the interrelationship with the team and users, and they are not able to separating these problems from your personal life, reinforcing the need for psychological support to minimize the experience in this context.

Health professionals find themselves immersed in a stressful daily work and begin to experience situations that require them to be more adaptable to psychological and emotional demands ${ }^{(25)}$. For professionals to be able to perform their function better safely, an investment in their health is necessary, in order to improve their professional life and ensure their safety ${ }^{(26)}$.

From an interactionist perspective, people give meaning to symbols and express them through language ${ }^{(13)}$. Thus, the recognition of what is or is not significant for professionals is possible when they interact, share information, perspectives and expectations about care ${ }^{(19)}$.

Unsafety due to verbal aggression was emphasized by the participants, which stems from users exalted by their demand not being met. Professionals, in an attempt to minimize user dissatisfaction, try to explain the situation and working conditions, which can cause even more commotion in users. Communication is considered in SI as a structure that instigates people's development, known as the window to true human nature ${ }^{(13)}$.

Exposure to violence can have psychological consequences, with a predominance of non-physical violence, with verbal abuse being the most common form. There is a need for interventions to protect health professionals and provide safer work environments, better work organization and training in communication skills, follow-up with adequate support for victims of violence ${ }^{(27)}$.

Another factor addressed was the location of the units in violent regions, making daily work safety difficult. Violence is a social problem with a strong impact on health and Professional Safety. In this context, health care and promotion of care in areas vulnerable to violence are included, commonly characterized by a precarious infrastructure, deprived of material living conditions and profound social inequalities ${ }^{(28)}$.

The skills of work in FHS require professionals to work outside the walls, often in places with a higher incidence of crime, which can cause professionals, at times, fear, and unsafety ${ }^{(23)}$.

Distress was reported due to the impotence of not meeting user demand due to system failures, lack of human and material resources. These factors are responsible for causing moral distress, anguish and distress because they know what needs to be done and are unable to provide users with adequate care. A study carried out in a city in Rio Grande do Sul, Brazil, corroborates this finding, by showing thin $\mathrm{PHC}$ professionals feel without resources to act conclusively to care for users, causing distress ${ }^{(22)}$. The lack of an organized and resolute system, interconnected in a network, is a limiting factor to good practices. 
Participants point to their love of working in $\mathrm{PHC}$ and their selffulfillment in solving users' demands, even with limited resources. The action and professional/user interaction allow professionals to give meaning and re-signify their perspectives in relation to health care, providing quality care within the possibilities.

Working involves relationships, which can result in satisfaction or dissatisfaction, directly implying professionals' work and the results of the care provided ${ }^{(23)}$. Among the reasons for job satisfaction are the affinity with the assistance/care provided, with the profession, the resolvability of the assistance offered to users, user satisfaction with the assistance received, the bond established between professionals and users ${ }^{(29)}$. Professional fulfillment, pride in what they do, satisfaction and identification with their tasks are experiences that cause well-being for professionals ${ }^{(22)}$. Among the factors of dissatisfaction, the following stand out: difficulties in collaboration of users and family members in the care process, low pay, devaluation of work, difficulties in working as a team, work overload and working in a place that is not their choice ${ }^{(8,29-30)}$.

Considering the constructs presented, it can be thought that Professional Safety is considered a significant symbol for the provision of quality care, since the symbol is considered a central concept, without which social interaction becomes impractical ${ }^{(19)}$.

The symbolic that makes up sociability is constructed and re-signified in the interactional action of people with the environment, which in this study is that of professional work in PHC safely. The sense and meaning of each professional participating in this study, of what their safety is, becomes a theoretical basis based on the doing and daily interactions/relationships of the individual "I", constructed by the "we" socially. In this way, the participants expose how the PHC context should be, explain what they understand by Professional Safety and what they experience in the services, since the environment, infrastructure and interrelationships at work and with users are part of their safety and the meanings attributed to it.

It is considered "that the relationship between the quality of care and patient safety is directly related to Professional Safety"(10).

Good practices in $\mathrm{PHC}$ were not directly addressed in the results of this study, but it can be inferred that there is a gap between the provision of means and resources for good practices and the infrastructure context of $\mathrm{PHC}$ and professionals' experiences. There are reports of feelings of incapacity due to the disrespectful treatment of users, negligence and difficulties in contemplating full access to services. However, it should be considered that good health practices can also be contemplated by welcoming, active and qualified listening, respectful treatment of users/family as well as by ethical, committed, safe, and resolute actions.

\section{Study limitations}

Failure to include PHC managers and coordinators as research participants was a limitation.

\section{Contributions to nursing and health}

Literature presents a broad discussion on Patient Safety over the last decade. The understanding of Professional Safety and the conceptual/theoretical formulation of this theme contributes to professional practice, since good practices and safe patient care are directly related to Professional Safety. It is suggested to carry out studies in other realities that replicate this theory about Professional Safety in Daily Life in PHC.

\section{FINAL CONSIDERATIONS}

This study made it possible to understand the Professional Safety phenomenon in daily life in PHC. The established theory can be designated as substantive when considering the conceptual formulation of safety, discovering their meanings and variations, bringing them together in a flexible and creative way through a microanalysis of the three realities studied, thus formulating a theory based on the experiences of professionals in 12 categories in operation in PHC.

When understanding Professional Safety, the evidence scales the professionals who feel able to perform their skills and competences; ethical and committed action to have safety, including the exercise of technical responsibility by nurses. The taste for working in PHC, cooperation in teamwork and interdisciplinarity contribute to safe actions, as well as access to resources for health work, including personal protective equipment. Psychological support and physical protection were indicative for Professional Safety. Professional Unsafety manifests itself in the lack of infrastructure, continuing education and support. Low resolution in $\mathrm{PHC}$ and in the system leads to professionals' dissatisfaction, frustration, and distress.

Safety culture imposes on professionals the responsibility for their own safety, that of their colleagues, patients and family members, reinforcing the blame for this responsibility. However, the co-responsibility between professionals, managers and users is indicated in the speeches of participants in daily work in PHC.

Reflecting on Professional Safety is essential, given the country's public health setting. SUS still faces challenges such as underfunding and precarious working conditions for professionals, negatively impacting the resolution of individual and collective demands in an appropriate and necessary time, and professionals need to leave the logic of what should be in order to be precise. It is suggested to carry out studies in other realities that replicate this theory about Professional Safety in Daily Life in PHC.

\section{FUNDING}

Notice 003/2017/PROPE/UFSJ, Institutional Program for Scientific Initiation Scholarships (PIBIC), scholarship granted by the Brazilian National Council for Scientific and Technological Development (CNPq - Conselho Nacional de Desenvolvimento Científico e Tecnológico), PIBIC/CNPq.

\section{REFERENCES}

1. Coutinho LRP, Barbieri AR, Santos MLM. Acolhimento na atenção primária à saúde: revisão integrativa. Saúde Debate. 2015;39(105):514-524. http://doi.org/10.1590/0103-110420151050002018 
2. Viegas SMF, Penna CMM. As dimensões da integralidade no cuidado em saúde no cotidiano da estratégia saúde da família no Vale do Jequitinhonha, MG, Brasil. Interface (Botucatu). 2015;19(55):1089-100. https://doi.org/10.1590/1807-57622014.0275

3. Baratto MAM, Pasa TS, Cervo AS, Dalmolin GL, Pedro CMP, Magnago TSBS. Culture of patient safety in the hospital setting: na integrative review. J Nurs UFPE. 2016;10(11):4126-36. https://doi.org/10.5205/1981-8963-v10i11a11500p4126-4136-2016

4. Klemenc-Ketis Z, Maletic M, Stropnik V, Deilkås ET, Hofoss D, Bondevik GT. The safety attitudes questionnaire - ambulatory version: psychometric properties of the Slovenian version for the out-of-hours primary care setting. BMC Health Serv Res. 2017;17:36. https://doi.org/10.1186/ s12913-016-1972-7

5. Fioreti FCCF, Manzo BF, Montenegro LC, Corrêa AR, Martins TCR, Costa DM. Use of quality management tools focusing on the safety of the neonatal patient. J Nurs UFPE. 2016;10(11):3883-9. https://doi.org/10.5205/reuol.9881-87554-1-EDSM1011201609

6. Rios MO, Nascimento MAA. Production of care for resolubility of the family health strategy: knowledge and dilemmas. J Nurs UFPE. 2017;11(9):3542-50. https://doi.org/10.5205/1981-8963-v11i9a234484p3542-3550-2017

7. Cavalcante AKCB, Cavalcante FA, Pires DCO, Batista EMCA, Nogueira LT. Nursing prerception of safety culture: integrative review. J Nurs UFPE. 2016;10(10):3890-7. https://doi.org/10.5205/1981-8963-v10i10a11457p3890-3897-2016

8. Soratto J, Pires DEP, Scherer MDA, Witt RR, Ceretta LB, Farias JM. Family Health Strategy professional satisfaction in Brazil: a qualitative study. Texto Contexto Enferm. 2020;29:e20180104. https://doi.org/10.1590/1980-265x-tce-2018-0104

9. Oliveira RM, Leitão IMTA, Silva LMS, Figueiredo SV, Sampaio RL, Gondim MM. Strategies for promoting patient safety: from the identification of the risks to the evidence-based practices. Esc Anna Nery. 2014;18(1):122-9. https://doi.org/10.5935/1414-8145.20140018

10. Gontijo MD, Viegas SMF, Freitas ATS, Maia AFF, Silveira EAA, Quites HFO.Professional safety constructs in the context of primary health care. Rev Bras Enferm 2020;73(suppl 6):e20190529. https://doi.org/10.1590/0034-7167-2019-0529

11. Nitschke RG, Tholl AD, Potrich T, Silva KM, Michelin SR, Laureano DD. Contributions of Michel Maffesoli's thinking to research in nursing and health. Texto Contexto Enferm. 2017;26(4):e3230017. https://doi.org/10.1590/0104-07072017003230017

12. Strauss A, Corbin J. Pesquisa qualitativa: técnicas e procedimentos para o desenvolvimento da teoria fundamentada. $2 \mathrm{a}$ ed. Porto Alegre: Artmed; 2008.

13. Blumer H. Symbolic interactionism: perspective and method. Englewood Cliffs, N.J.: Prentice-Hall; 1969.

14. Tong A, Sainsbury $P$, Craig J. Consolidated criteria for reporting qualitative research (COREQ): a 32-item checklist for interviews and focus groups. Int J Qual Health Care. 201719(6):349-57. http://doi.org/10.1093/intqhc/mzm042

15. Morin E. Ciência com consciência. Rio de Janeiro: Bertrand Brasil; 2005.

16. Leite DF, Nascimento DDG, Oliveira MAC. Qualidade de vida no trabalho de profissionais do NASF no município de São Paulo. Physis. 2014;24(2):507-25. https://doi.org/10.1590/S0103-73312014000200010

17. Viana DMS, Araújo RS, Vieira RM, Nogueira CA, Oliveira VC, Rennó HMS. A educação permanente em saúde na perspectiva do enfermeiro na estratégia de saúde da família. Rev Enferm Centro Oeste Mineiro. 2015;5(2):1658-68. https://doi.org/10.19175/recom.v0i0.470

18. Martins JRT, Alexandre BGP, Oliveira VC, Viegas SMF. Permanent education in the vaccination room: what is the reality?. Rev Bras Enferm. 2018;71(suppl 1):668-76. http://doi.org/10.1590/0034-7167-2017-0560

19. Utzumi FC, Lacerda MR, Bernardino E, Gomes IM, Aued GK, Sousa SM. Continuity of care and the symbolic interactionism: a possible understanding. Texto Contexto Enferm. 2018;27(2):e4250016. https://doi.org/10.1590/0104-070720180004250016

20. Caçador BS, Brito MJM, Moreira DAR, Rezende LC, Vilela CS. Being a nurse in the family health strategy programme: challenges and possibilities. REME Rev Mineira Enferm. 2015;19(3):612-61. https://doi.org/10.5935/1415-2762.20150047

21. Conselho Federal de Enfermagem (BR). Resolução n 509 de 15 de março de 2016. Atualiza a norma técnica para Anotação de Responsabilidade Técnica pelo Serviço de Enfermagem e define as atribuições do enfermeiro Responsável Técnico [Internet]. Brasília, DF: COFEN; 2016 [cited 202109 10]. Available from: http://www.cofen.gov.br/resolucao-cofen-no-05092016-2_39205.html

22. Maissiat GS, Lautert L, Dal Pai D, Tavares JP. Work context, job satisfaction and suffering in primary health care. Rev Gaucha Enferm. 2015;36(2):42-9. https://doi.org/10.1590/1983-1447.2015.02.51128

23. Soratto J, Pires DEP, Trindade LL, Oliveira JSA, Forte ECN, Melo TP. Job dissatisfaction among health professionals working in the family health strategy. Texto Contexto Enferm. 2017;26(3):e2500016. https://doi.org/10.1590/0104-07072017002500016

24. Vieira AN, Lima DWC, Silva FT, Oliveira GWS. Use of personal protective equipment for nursing professional in primary health care. J Nurs UFPE. 2015;9(suppl 10):1376-83. http://doi.org/10.5205/reuol.8463-73861-2-SM.0910sup201501

25. Rodrigues CCFM, Santos VEP, Sousa P. Patient safety and nursing: interface with stress and Burnout Syndrome. Rev Bras Enferm. 2017;70(5):1083-8. https://doi.org/10.1590/0034-7167-2016-0194

26. Bodenheimer T, Sinsky C. From triple to quadruple aim: care of the patient requires care of the provider. Ann Fam Med. 2014;12(6):573-6. https://doi.org/10.1370/afm.1713

27. Fisekovic MB, Trajkovic GZ, Bjegovic-Mikanovic VM, Terzic-supic ZJ. Does workplace violence exist in primary health care?: evidence from Serbia. Eur J Public Health. 2015;25(4):693-98. https://doi.org/10.1093/eurpub/cku247

28. Santos MS, Silva JG, Branco JGO. Fighting violence under the family health strategy: challenges for health care. Rev Bras Promoc Saude. 2017;30(2):229-38. https://doi.org/10.5020/18061230.2017.p229 
29. Lima L, Pires DEP, Forte ECN, Medeiros F. Job satisfaction and dissatisfaction of primary health care professionals. Esc Anna Nery. 2014;18(1):17-24. https://doi.org/10.5935/1414-8145.20140003

30. Munyewende PO, Rispel LC, Chirwa T. Positive practice environments influence job satisfaction of primary health care clinic nursing managers in two South African provinces. Hum Resour Health. 2014;12:27. https://doi.org/10.1186/1478-4491-12-27 